\title{
Receptor localization of steroid hormones and drugs: discoveries through the use of thaw-mount and dry-mount autoradiography
}

W.E. Stumpf

\author{
Correspondence \\ W.E. Stumpf \\ 2612 Damascus Church Road \\ Chapel Hill, NC 27516 \\ USA \\ Fax: 001 (919) 942-8646 \\ E-mail: stumpfwe@email.unc.edu
}

Presented at the 5 th International Symposium on Radioautography, São Paulo, SP, Brasil,

August 24-26, 1997.

Received July 11, 1997 Accepted July 23, 1997
University of North Carolina at Chapel Hill, and

International Institute of Drug Distribution,

Cytopharmacology and Cytotoxicology, Chapel Hill, NC, USA

\section{Abstract}

The history of receptor autoradiography, its development and applications, testify to the utility of this histochemical technique for localizing radiolabeled hormones and drugs at cellular and subcellular sites of action in intact tissues. Localization of diffusible compounds has been a challenge that was met through the introduction of the "thawmount" and "dry-mount" autoradiographic techniques thirty years ago. With this cellular receptor autoradiography, used alone or combined with other histochemical techniques, sites of specific binding and deposition in vivo and in vitro have been characterized. Numerous discoveries, some reviewed in this article, provided information that led to new concepts and opened new areas of research. As an example, in recent years more than fifty target tissues for vitamin $D$ have been specified, challenging the conventional view about the main biological role of vitamin D. The functions of most of these vitamin D target tissues are unrelated to the regulation of systemic calcium homeostasis, but pertain to the (seasonal) regulation of endo- and exocrine secretion, cell proliferation, reproduction, neural, immune and cardiovascular responses, and adaptation to stress. Receptor autoradiography with cellular resolution has become an indispensable tool in drug research and development, since information can be obtained that is difficult or impossible to gain otherwise.

\section{Identification of cellular-subcellular sites of specific receptor binding, a requirement for understanding related mechanisms of action of autacoids and xenobiotics}

During a decade of clinical work in neurology and psychiatry in the 1950s, I realized the need for finding out "where it goes". New drugs with considerable side effects were introduced. Their mode of action was poorly understood. Autoradiography with radiolabeled
Key words

- Vitamin D

- Steroid hormones

- Receptors

- Autoradiography

- Drug distribution

- Localization agents appeared to be a suitable first approach for gaining information about the location of brain targets and related actions. However, available techniques were based on the use of conventional tissue fixation and embedding, during which most of the labeled compound was translocated and lost. With frozen brain slices, or frozen sections mounted on Scotch tape, sandwiched with X-ray film, some crude regional resolution has been achieved in other laboratories. Fine regional and cellular resolution was needed. 
Light microscopic cellular autoradiography of diffusible compounds was considered "not possible", as Hilde Levy remarked with a smile when I inquired during her seminar discussion at the University of Chicago in 1964. Hilde Levy (1), previously coworker of two Noble laureates, Hevesy and Libby, endeavoured for several years to localize radiolabeled testosterone, with little or no success.

\section{Development and testing of techniques}

In 1963, I occupied a small laboratory in the Department of Pharmacology at the University of Chicago, "to start from scratch" with the objective of developing a technique for "high-resolution light microscopic autoradiography for the localization of diffusible compounds". Any step that could be a potential source of translocation and leaching needed to be excluded from the procedure, without sacrificing resolution. This eliminated traditional approaches, such as lowresolution film apposition techniques, or procedures that employ liquid fixation, embedding, and liquid emulsion.

Concurrently, the experienced histologist Isidore Gersh in the Department of Anatomy at the University of Chicago pursued the same problem by trying to localize ${ }^{14} \mathrm{C}$ glucose. He employed freeze-drying of tissue, vapor fixation, embedding in wax or plastic, and liquid emulsion-dipping. After photographic exposure, Gersh photographed first the beta-tracks in the emulsion at different focal planes and subsequently the superimposed negatives in order to trace the tissue origin of the beta-radiation. This procedure was complicated, of insufficient resolution, and retention of label was compromised by the use of embedding medium and liquid emulsion. Similar unsuited techniques were advocated in the literature at that time. One of the more common techniques was based on apposition of a section-mounted slide and an emulsion-coated slide as a sandwich for photographic exposure, followed by disassembly for separate processing and staining after exposure, and reassembly and realignment for microscopic viewing. Realignment between recorded silver grains and related histological structure was cumbersome and remained unsatisfactory. The possibilities available for realignment were the use of radioactive ink, a hinged (one edge glued) emulsion-coated cover glass, or even a double-microscope connected by an optical bridge for simultaneous viewing of two slides, one with the tissue structure and the other with the radiation record. None of these apposition techniques achieved cellular resolution, and even regional resolution was lacking detail.

As varied as the recommended "new" techniques were the results obtained. For instance, for the localization of estrogen, five reports with five different techniques had been published in the literature, all yielding differing results that were specific and reproducible for each technique (2). In my own studies with six different techniques, using two diffusible compounds, ${ }^{3} \mathrm{H}$-estradiol and ${ }^{3} \mathrm{H}$-mesobilirubinogen, the drymount technique that excluded most rigorously any liquid phase showed the most selective and expected cellular, subcellular, and organ distribution (3). Continued careful experiments, concerned with optimizing the freezing of tissue, freeze-drying, frozen sectioning, and other steps of the procedure, established the utility of what has become known as the thaw-mount and dry-mount autoradiographic techniques $(3,4)$. Since 1964, when the first report was published (5), these techniques have been extensively applied in our laboratory, utilized in other laboratories, and adapted to a combined use with different histochemical techniques $(6,7)$.

Thirty years after their introduction, it can be stated that these techniques stood the test of time. The more expedient thaw-mount autoradiographic technique is now widely 
used and has been copied by several laboratories. The conceptually more rigorous but technically more demanding dry-mount technique involves freeze-drying, handling of freeze-dried sections, and pressure for close contact between section and emulsion. Thawmounting, as the name implies, employs melting of thin 2-4- $\mu \mathrm{m}$ frozen sections. Although both are tested methods of choice for the localization of diffusible compounds, during thaw-mounting, chemography and limited diffusion may occur, especially with sections thicker than $4 \mu \mathrm{m}$; therefore, controls are needed. Controls for diffusion and chemographic artifacts can be done with the dry-mount technique, 0-day exposure, and samples without radioactivity (8).

The importance of the dry-mount technique has been demonstrated for the study of skin, which contains mucopolysaccharides and other extracellular components of connective tissue that may produce chemographic artifacts during thaw-mounting but can be avoided with dry-mounting (9). Diffusion - albeit limited - during thaw-mounting of frozen sections, has restricted the cellular localization of highly diffusible compounds such as glucose and 2-deoxyglucose. Cellular localization of these highly diffusible sugars has been achieved, however, with the dry-mount technique that led to the identification of "high activity glial cells" in various brain regions and of specific "high activity neurons" in the lower brain stem of resting and non-stressed animals (10). Such cellular resolution has never been achieved in previous 2-deoxyglucose studies, published in the literature, with the standard whole body autoradiography.

Details of the thaw-mount and dry-mount techniques have been published (11-14). With these techniques, a computation of the number of molecules, related to the number of silver grains per subcellular compartment, is possible and is based on the assessment of the silver grain yield under the specific experimental conditions. A specific average yield of 16.6 disintegrations per silver grain has been assessed for $4-\mu \mathrm{m}$ sections of rat uterus thaw-mounted on Kodak NTB 3. The numbers of occupied nuclear receptors estimated for estradiol and vitamin D, calculated from autoradiograms $(15,16)$, correspond to those determined by biochemical procedures.

\section{Discoveries, related new concepts and paradigms through the use of thaw-mount and dry-mount autoradiography}

Numerous contributions have been made. Frequently, the provided information resulted in new concepts and new areas of research were opened. The following is a selection of contributions from our laboratory in chronological order.

1964. Freeze-drying of 1-4- $\mu \mathrm{m}$ frozen sections and dry-mounting of freeze-dried unfixed and unembedded sections on desiccated emulsion-coated slides were achieved. First evidence was provided for a successful use of a dry autoradiographic technique with cellular and subcellular resolution (5).

1965. Frozen sectioning was achieved at low temperatures of -60 to $-105^{\circ} \mathrm{C}(17)$. Cutting below $-40^{\circ} \mathrm{C}$ was previously considered not possible, since "the tissue becomes friable and crumbles" (18). Relationships between section thickness and cutting temperature were recognized: low temperatures facilitate and limit cutting of thin sections, while high temperatures facilitate and limit cutting of thick sections. The first successful demonstration of frozen sections cut below $-100^{\circ} \mathrm{C}$, with minimal ice crystal disruption and preservation of high resolution structure, opened a new era of cryo-microtomy for high resolution light and electron microscopy (17).

1966. Dry-mount and thaw-mount autoradiography for diffusible compounds was established through control experiments and comparison with results from different techniques: different techniques produced dif- 
ferent results with both results and artifacts being reproducible. Nuclear concentration of ${ }^{3} \mathrm{H}$-estradiol in rat uterus was demonstrated for the first time (3).

1967. Design of a portable Cryosorption Pump for the freeze-drying of tissue and of the Wide-Range Microtome Cryostat for the cutting and handling of thin frozen sections (19).

1968. First demonstration of nuclear estradiol receptor distribution in target neurons in the diencephalon at projection sites of the stria terminalis. The related new concept of "estrogen-neuron circuits" contradicted existing concepts of "the hypothalamic sex center" and "the hypophyseotrophic area". First evidence and a map were provided of estrogen target neurons in the ventromedial nucleus pars lateralis, paraventricular nucleus, medial preoptic nucleus, lateral hypothalamus, premammillary nucleus, all projection sites of the stria terminalis (20).

Discovery of nuclear estrogen receptors in all anterior pituitary cell types and in pituicytes (21).

1969. Estrogen receptors in ovarian granulosa and theca interna cells, oviduct, uterus, vagina, and testis Leydig cells $(22,23)$.

1970. Demonstration of estradiol target neurons throughout the brain with predominance in periventricular neuronal groups, including the nucleus of the solitary tract in the medulla oblongata. The first comprehensive brain map for "estrogen neurons" was published and on that basis the concept of "estrogen-neuron systems in the periventricular brain" proposed (24). Androgen receptors in prostate and epididymis (25).

1972. Glucocorticoid receptor distribution was first reported in specific brain hypothalamic and extrahypothalamic (hippocampus, amygdala) sites (26). Androgen receptors in the pituitary (27).

1973. Androgen receptors in the brain (28). Estrogen target neurons in thoracic and lumbar spinal cord (29). Progestagen receptors in brain (30). Estrogen receptors in skin epidermis, fibroblasts, and hair dermal papillae (31). Thyroid hormone nuclear and cytoplasmic localization in pituitary and brain $(32,33)$.

1975. Development of a technique for combined autoradiography-immunohistochemistry for colocalization of steroid and peptide hormones in pituitary and brain (34). Development of a technique for combined autoradiography and catecholamine fluorescence for the colocalization of estradiol or dihydrotestosterone and catecholamine in the hypothalamus and hindbrain $(6,35)$.

Demonstration of optic-thalamic neural projection from the retina to the thalamic nucleus anterodorsalis in tree shrew (36).

Estrogen nuclear receptors mapped in the brain of representatives of vertebrate phyla: primate $(37,38)$, fishes and reptiles (39), and mammals (40).

1976. Estrogen receptors demonstrated in thymus reticular cells and Hassal's corpuscles (41).

1977. Estrogen receptors in myocytes of heart atrium; postulating estrogen effects on manufacture and secretion of a hypothetical "heart hormone" (42), later identified as atrial natriuretic factor (ANF).

Demonstration and mapping of androgen receptors in motor neurons of cranial nerves and spinal cord (43).

1979. Vitamin D nuclear receptors discovered in non-calcemic tissues: anterior and posterior pituitary, skin epidermis and outer hair sheath, pylorus enteroendocrine cells, kidney macula densa and podocytes (44).

Aldosterone receptor neuron distribution mapped in rat forebrain and hindbrain (45).

1980. Vitamin D nuclear receptors discovered and mapped in brain and cervical spinal cord (46-48).

1981. Vitamin D nuclear receptors identified in pancreas B-cells with demonstration of vitamin D-mediated insulin secretion $(49,50)$, in thymus reticular cells, heart muscle, salivary glands, esophagus and others (51). Demonstration of vitamin D nuclear 
receptor binding in thyrotropes and effects on TSH secretion and TSH blood levels $(52,53)$. Discovery and designation of the nucleus olfacto-retinalis in fishes that contains GnRH-neurons with dual projections to the olfactory epithelium and the retina (together with Muenz and Jennes (54)).

1983. Vitamin D nuclear receptors in osteoblasts of bones from fetal rats (54).

1984. Concept of "A-B-C (allocortexbrainstem-core) circuitry" of autonomic-endocrine peptidergic-aminergic steroid-regulated neurons; proposed as alternate or complement to the "limbic system" concept (55).

1986. Vitamin D nuclear receptors demonstrated in adrenal medulla; non-congruency with calcium-binding protein containing cells (56). Vitamin D nuclear receptors in different cell types of rodent and human teeth $(57,58)$.

1987. Vitamin D receptors in male reproductive organs: Sertoli cells (with preference in defined spermatogenic stages), ductuli efferentes, epididymis, prostate, seminal vesicles, ductus deferens $(59,60)$.

The concept of "vitamin D-soltriol as seasonal activator and regulator of vital functions" was offered in lieu of the contemporary concept, "vitamin D the calcium homeostatic steroid hormone" (61-63).

1988. Vitamin D receptor neurons were demonstrated and anatomically defined in segments of the spinal cord and spinal ganglia (64). Vitamin D nuclear binding in stomach G-cells and pyloric sphincter muscle (65).

1989. Vitamin D receptors in female reproductive organs: ovary germinal epithelium, oviduct and uterus (66).

1990. Phylogeny of vitamin D receptors detailed in fishes, amphibia, and reptiles (67-70) in support of our concept of "vitamin $\mathrm{D}$, a seasonal regulator of biological functions".

Ecdysteroid localization and mapping of ecdysteroid target cells in Manduca sexta larvae (71).
High activity 2-deoxyglucose neurons identified in lower brain stem of resting animals (13).

Estrogen and progestin receptor neurons mapped in brain cortex of postnatal mice $(72,73)$.

1991. Vitamin D nuclear receptors in hamster choroid plexus and ependyma (74). Mapping of vitamin D receptors in the heart and first observation of vitamin $\mathrm{D}$ genomic effects on heart ANF secretion (75).

Retinoic acid nuclear receptors in adult brain, pituitary and retina (76).

1993. Vitamin D and progestagen nuclear binding sites in male sex organs of the Siberian hamster (77) and mouse (78).

1994. Vitamin D nuclear receptor binding of ${ }^{3} \mathrm{H}-1,25(\mathrm{OH})_{2}$ vitamin $\mathrm{D}_{3}$ and its oxygen analog ${ }^{3} \mathrm{H}-\mathrm{OCT}$ in developing bone osteoblasts and hypertrophic chondrocytes. The observations suggest that hypertrophic chondrocytes at the epiphyseal growth plate do not die, contrary to current text book teaching. Strong nuclear binding was demonstrated in hypertrophic cells in open lacunae of cartilage at the border to the primary spongiosa in unembedded, unfixed and undecalcified sections, which argues for survival of hypertrophic chondrocytes (79).

1995. Discovery of vitamin D, and its analog OCT, nuclear receptors in the neckisthmus region of gastric glands, which suggests regulatory effects on the renewal and turnover of gastric gland cell types (80). Vitamin D increases expression of the tyrosine hydroxylase gene in adrenal medullary cells (81).

A comparison between results from radioassays and autoradiography reveals that by conventional radioassays, as used for drug development studies at pharmaceutical companies, the number of tissues that concentrate radioactivity after injection of radiolabeled vitamin $\mathrm{D}$ amounts to about six or eight, while by receptor autoradiography over 50 different tissues could be identified (82). 1996. Compared to the very limited re- 
sults from the use of radioassay-HPLC or whole body autoradiography, the importance of receptor autoradiography for drug development and targeting has been stressed in the coinage: Corpora non agunt nisi in loco apto (83).

\section{Discussion}

The introduction of the thaw-mount and dry-mount techniques was a conceptual and technical breakthrough in autoradiography as well as in cryo-histology. The cutting of thin frozen sections at low temperatures, preservation of fine structure in freeze-dried and thaw-mounted thin sections, and the related preservation of tissue components and labeled compounds at their original sites, all without the conventional fixation and embedding, were decisive accomplishments that provided a basis for new applications and discoveries that followed in rapid succession.

Success was related to following the premise of studying the 'unmolested tissue', i.e., minimizing treatment, eliminating all unnecessary steps, and carefully observing and controlling each step in the procedure. In order to preserve the in vivo state, postmortem changes, ice crystal disruption during freezing, storage and handling of tissue, and diffusion during brief melting of the thin section for adhesion to the emulsion, all must be avoided or kept minimal. Therefore, dissection over ice, simultaneous freezemounting of tissue blocks to holders, storage of the chuck-mounted specimen in liquid nitrogen, cutting of frozen sections at $4 \mu \mathrm{m}$ or thinner, avoidance of even brief warming of tissue and sections, are all essential. Similar attention has to be given to the preparation of nuclear emulsion-coated slides, storage of the section-mounted slides under low humidity at low temperatures, and brief, preferably single step, staining after photographic processing.

While it is difficult to assess the impact of a new technique, the selected list of dis- coveries from our laboratory may speak for itself. In addition, there are contributions from other laboratories. The thaw-mount autoradiographic technique has been used by others, for instance, in the discoveries of sex-dimorphic neurons in the midbrain of a songbird (85) and in the spinal cord lumbar region of the rat (86), or the identification of aldosterone target neurons in regions of the forebrain (87).

Claims in the literature about restricted "centers" in the hypothalamus and the concept of the "hypophyseotrophic area" for the regulation of pituitary functions, as well as the "limbic system" concept have been challenged on the basis of our data. Our alternate concepts instead pointed toward the existence of circuitries, or systems, of steroid target neurons that involve many regions, not only in the forebrain, but also in midbrain, hindbrain, and even the spinal cord. From the new information on variable nuclear labeling in the periventricular brain, the MAHS concept proposed a differential "multiple activation of heterogeneous systems" for brain actions of sex steroids, gluco- and mineralocorticoids, and seasonal regulatory steroid vitamin D (88). This MAHS concept, based on steroid receptor binding and function hierarchy in different cell populations, while derived from observations in the brain, appears to be valid also for other tissues.

The wide and unexpected distribution of estrogen target cells outside of "reproductive organs", noted in our autoradiograms, e.g., in brain hypothalamic and extrahypothalamic sites, in pituitary cell types, pineal, skin, thymus, heart, testis, kidney, etc., startled many scientists ("oh, it's everywhere - what does it mean!" was a frequent response after publication of the new data during the late 1960s and early 1970s). Similarly, the wide and unexpected distribution of vitamin D target tissues reported during the late 1970s and early 1980s was met with varied responses. Since the new data frequently did not support the conventional and 
narrow "vitamin D-calcium" concept, their reception was mixed. Some scientists ignored the new data, some rejected or depreciated them ("oh, these are only a few cells in the pituitary, it does not matter"), some followed-up quickly with biochemical identification of related receptor protein, while a few responded with genuine interest and recognition.

Discoveries through the use of autoradiography and related new concepts frequently encountered initial resistance or rejection by others. Rejection of related research proposals by anonymous "peer" reviewers was the rule rather than the exception. All that corresponds to Kuhn's (89) analysis of progress in science and the introduction of new paradigms. A case in point is the tenacity of resistance in the replacement of the above mentioned erroneous concepts, such as "the sex center", "the hypophyseotrophic area", "the limbic system", and vitamin D as "the calcium homeostatic steroid hormone", all challenged through the above listed findings. Investigators, under pressure of time and competition, maintain the convenient paradigms that dominate the secondary literature and reviews, apparently without consulting the original contributions. Although scrutiny of primary sources would be imperative for the sake of evidence and truth, this logistic tedium is often evaded for reasons of expediency, "productivity", or competitive gain.

At times, progress of work has been affected by denials of support for research proposals submitted to the NIH and the National Science Foundation, through a "peer" review system that unfortunately does not permit peer correction of "peer" judgement. In the present system, rebuttals and criticism of anonymous "peer" reviewers' improper or incompetent comments are in general not honored. Rather, resubmission of application with deleterious loss of time and effort is required (90).

For proposals on histochemical research with vitamin $\mathrm{D}$ or other steroids (there is no Histochemistry Study Section), here are a few samples of anonymous "peer" comments with which denials of support were justified: "Autoradiography alone does not make a proposal, it only makes a map." "The P.I.'s finding that pancreatic islets contain vitamin $\mathrm{D}$ binding cells is interesting, but hardly the basis for full research proposal." "The problem to be studied by Dr. Stumpf appears to be moderately important but not in the mainstream of current islet research." (NSF reviewer's comments. 1981. Project title: Steroid hormone actions on endocrine pancreas). "The results of this work would only be confirmatory of biochemical data already available." "The author's effort, though 'labor intensive', is merely the application of a technique." (NSF proposal DCB-8518935. Title: Histochemistry of $1,25(\mathrm{OH})_{2}$ vitamin $\mathrm{D}_{3}$ receptors. 1986).

Despite extraordinary difficulties inherent in the subject matter and obstacles through anonymous "peer" incompetent judgements and statements with adverse consequences for funding, the original goal has been achieved. The goal was to obtain insight into sites and mechanisms of action by being able to localize with confidence, at the cellular and regional levels, bioactive compounds and hormonal messengers in brain and other tissues.

At first, techniques had to be developed that were considered very difficult or impossible and that had been attempted by several investigators without success. The technical achievements have been seminal in the development of cryo-histochemistry, in addition to the numerous applications of autoradiography.

Secondly, applications of the new autoradiographic techniques and follow-up led to discoveries that opened new directions of research, as indicated in this review. With the resulting extensions of our knowledge base, established concepts changed and new paradigms emerged. 


\section{References}

1. Levy H (1969). Attempts at an autoradiographic localization of labeled steroid hormone in tissue. In: Roth LJ \& Stumpf WE (Editors), Autoradiography of Diffusible Substances. Academic Press, New York, 113-120.

2. Stumpf WE (1968). High-resolution autoradiography and its application to in vitro experiments. In: Hayes RL, Goswitz FA \& Murphy BPE (Editors), Radioisotopes in Medicine: In Vitro Studies. AEC Symposium Series No. 13 (CONF-671111), Oak Ridge, TN, 633-680.

3. Stumpf WE \& Roth LJ (1966). High resolution autoradiography with dry-mounted, freeze-dried, frozen sections: Comparative study of six methods using two diffusible compounds, ${ }^{3} \mathrm{H}$-estradiol and ${ }^{3} \mathrm{H}$ mesobilirubinogen. Journal of Histochemistry and Cytochemistry, 14: 274-287.

4. Stumpf WE (1971). Autoradiographic techniques and the localization of estrogen, androgen and glucocorticoid in pituitary and brain. American Zoologist, 11: 725-739.

5. Stumpf WE \& Roth LJ (1964). Vacuum freeze-drying of frozen sections for drymounting, high-resolution autoradiography. Stain Technology, 39: 219-223.

6. Grant LD \& Stumpf WE (1975). Hormone uptake sites in relation to CNS biogenic amine systems. In: Stumpf WE \& Grant LD (Editors), Anatomical Neuroendocrinology. S. Karger, Basel, 445-464.

7. Sar M \& Stumpf WE (1981). Combined autoradiography and immunohistochemistry for simultaneous localization of radioactively labeled steroid hormones and antibodies in the brain. Journal of Histochemistry and Cytochemistry, 29 (1A): 161-166.

8. Stumpf WE \& Pilgrim Ch (1995). Artifacts in autoradiography. In: Stumpf WE \& Solomon HF (Editors), Autoradiography and Correlative Imaging. Academic Press, San Diego, 67-80.

9. Bidmon H-J, Pitts JD, Solomon HF, Bondi JV \& Stumpf WE (1991). Estradiol distribution and penetration in rat skin after topical application, studied by high resolution autoradiography. Histochemistry, 95: 43-54.

10. Duncan GE, Kaldas RG, Mitra KE, Breese GR \& Stumpf WE (1990). High activity neurons in the reticular formation of the medulla oblongata: A high-resolution autoradiographic 2-deoxyglucose study. Neuroscience, 35: 593-600.
11. Stumpf WE (1976). Techniques for the autoradiography of diffusible compounds. In: Prescott DM (Editor), Methods in Cell Biology. Vol. XIII. Academic Press, New York, 171-193.

12. Stumpf WE \& Duncan GE (1990). High resolution autoradiographic mapping of drug and hormone receptors. In: Conn PM (Editor), Qualitative and Quantitative Microscopy. Vol. 3. Methods in Neurosciences. Academic Press, San Diego, 3550.

13. Duncan GE \& Stumpf WE (1990). High resolution autoradiographic imaging of brain activity patterns with radiolabeled 2deoxyglucose and glucose. In: Conn PM (Editor), Qualitative and Quantitative Microscopy. Vol. 3. Methods in Neurosciences. Academic Press, San Diego, 50-64.

14. Shughrue PJ \& Stumpf WE (1995). Rapid high resolution steroid autoradiography. In: Stumpf WE \& Solomon HF (Editors), Autoradiography and Correlative Imaging. Academic Press, San Diego, 129-150.

15. Stumpf WE, Sar M, Zuber TJ, Soini E \& Tuohimaa P (1982). Quantitative assessment of steroid hormone binding sites by thaw-mount autoradiography. Journal of Histochemistry and Cytochemistry, 5: 1403-1405.

16. Clark SA, Stumpf WE, Sar M \& DeLuca HF (1987). 1,25-Dihydroxyvitamin $D_{3}$ target cells in immature pancreatic islets. American Journal of Physiology, 253: E99E105.

17. Stumpf WE \& Roth LJ (1965). Thin sections cut at temperatures of $-70^{\circ}$ to $-90^{\circ} \mathrm{C}$. Nature, 205: 712-713.

18. Pearse AG (1968). Histochemistry. 3rd edn. Little \& Brown, Boston.

19. Stumpf WE \& Roth LJ (1967). Freezedrying of small tissue samples and thin frozen sections below $-60^{\circ} \mathrm{C}$ : A simple method of cryosorption pumping. Journal of Histochemistry and Cytochemistry, 15: 243-251.

20. Stumpf WE (1968). Estradiol concentrating neurons: Topography in the hypothalamus by dry-mount autoradiography. Science, 162: 1001-1003.

21. Stumpf WE (1968). Cellular and subcellular ${ }^{3} \mathrm{H}$-estradiol localization in the pituitary by autoradiography. Zeitschrift für Zellforschung, 92: 23-33

22. Stumpf WE (1968). Subcellular distribution of ${ }^{3} \mathrm{H}$-estradiol in rat uterus by quantitative autoradiography. A comparison between ${ }^{3} \mathrm{H}$-estradiol and ${ }^{3} \mathrm{H}$-norethynodrel. Endocrinology, 83: 629-632.
23. Stumpf WE (1969). Nuclear concentration of ${ }^{3} \mathrm{H}$-estradiol in target tissues. Drymount autoradiography of vagina, oviduct, ovary, testis, mammary tumor, liver and adrenal. Endocrinology, 85: 31-37.

24. Stumpf WE (1970). Estrogen-neurons and estrogen-neuron systems in the periventricular brain. American Journal of Anatomy, 129: 207-218.

25. Sar M, Liao S \& Stumpf WE (1979). Nuclear concentration of androgens in rat seminal vesicles and prostate by autoradiography. Endocrinology, 86: 1008-1011.

26. Stumpf WE \& Sar M (1972). Topography of extrahypothalamic glucocorticosteroid "feedback" sites in the rat brain. Fourth International Congress on Endocrinology. Excerpta Medica, International Congress Series, 256: 120-121.

27. Sar M \& Stumpf WE (1973). Cellular and subcellular localization of radioactivity in the rat pituitary after injection of $1,2-{ }^{3} \mathrm{H}-$ testosterone using dry-autoradiography. Endocrinology, 92: 631-635.

28. Sar M \& Stumpf WE (1973). Autoradiographic localization of radioactivity in the rat brain after the injection of $1,2-{ }^{3} \mathrm{H}$-testosterone. Endocrinology, 92: 251-256.

29. Keefer DA, Stumpf WE \& Sar M (1973). Topographical localization of estrogenconcentrating cells in the rat spinal cord following ${ }^{3} \mathrm{H}$-estradiol administration. Proceedings of the Society for Experimental Biology and Medicine, 143: 414-417.

30. Sar M \& Stumpf WE (1973). Neurons of the hypothalamus concentrate ${ }^{3} \mathrm{H}$-progesterone or metabolites of it. Science, 182: 1266-1268.

31. Stumpf WE, Sar M \& Joshi SG (1974). Estrogen target cells in the skin. Experientia, 30: 196-198.

32. Stumpf WE \& Sar M (1973). Concentration of radioactivity in anterior pituitary cells, the posterior pituitary, ependymal cells of the median eminence and basal tuberal region after injection of $125 \mathrm{I}-\mathrm{la}$ beled thyroxine and triiodothyronine. Endocrinology, 92 (Suppl): 197 (Abstract 273).

33. Stumpf WE \& Sar M (1975). Localization of thyroid hormone in the mature rat brain and pituitary. In: Stumpf WE \& Grant LD (Editors), Anatomical Neuroendocrinology. S. Karger, Basel, 318-327.

34. Keefer DA, Stumpf WE, Petrusz P \& Sar M (1975). Simultaneous autoradiographic and immunohistochemical localization of estrogen and gonadotropin in the rat pituitary. American Journal of Anatomy, 142: 129-135. 
35. Heritage AS, Stumpf WE, Sar M \& Grant LD (1980). Brainstem catecholamine neurons are target sites for sex steroid hormones. Science, 207: 1377-1379.

36. Conrad CD \& Stumpf WE (1975). Direct visual input to the limbic system: Crossed retinal projections to the nucleus anterodorsalis thalami in the tree shrew. Experimental Brain Research, 23: 141-149.

37. Keefer DA \& Stumpf WE (1975). Atlas of estrogen-concentrating cells in the central nervous system of the squirrel monkey. Journal of Comparative Neurology, 160: 419-442.

38. Martinez-Vargas MC, Stumpf WE \& Sar M (1975). Estrogen localization in dove brain: Phylogenetic considerations and implications for nomenclature. In: Stumpf WE \& Grant LD (Editors), Anatomical Neuroendocrinology. S. Karger, Basel, 166-175.

39. Kim YS, Stumpf WE, Sar M \& MartinezVargas MC (1978). Estrogen and androgen target cells in the brain of fishes, reptiles and birds: Phylogeny and ontogeny. American Zoologist, 18: 425-433.

40. Stumpf WE \& Sar M (1978). Anatomical distribution of estrogen, androgen, progestin, corticosteroid and thyroid hormone target sites in the brain of mammals: Phylogeny and ontogeny. American Zoologist, 18: 435-445.

41. Stumpf WE \& Sar M (1976). Autoradiographic localization of estrogen, androgen, progestin and glucocorticosteroid in "target tissues" and "non-target tissues". In: Pasqualini J (Editor), Receptors and Mechanism of Action of Steroid Hormones. Modern Pharmacology-Toxicology. Vol. 8. Marcel Dekker, New York, 41-84.

42. Stumpf WE, Sar M \& Aumueller G (1977). The heart: A target organ for estradiol. Science, 196: 319-321.

43. Sar M \& Stumpf WE (1977). Androgen concentration in motor neurons of cranial nerves and spinal cord. Science, 197: 7779.

44. Stumpf WE, Sar M, Reid FA, Tanaka Y \& DeLuca HF (1979). Target cells for 1,25dihydroxyvitamin $D_{3}$ in intestinal tract, stomach, kidney, skin, pituitary and parathyroid. Science, 206: 1188-1190.

45. Birmingham MK, Stumpf WE \& Sar M (1979). Nuclear localization of aldosterone in rat brain cells, assessed by autoradiography. Experientia, 35: 1240-1241.

46. Stumpf WE, Sar M, Clark SA, Lieth E \& DeLuca HF (1980). Target neurons for $1,25(\mathrm{OH})_{2}$ vitamin $D_{3}$ in brain and spinal cord. Neuroendocrinology Letters, 2: 297301.
47. Stumpf WE, Sar M, Clark SA \& DeLuca HF (1982). Brain target sites for 1,25-dihydroxyvitamin $D_{3}$. Science, 215: 14031405.

48. Stumpf WE \& O'Brien LP (1987). Autoradiographic studies with ${ }^{3} \mathrm{H} 1,25$ dihydroxyvitamin $\mathrm{D}_{3}$ in thyroid and associated tissues of the neck region. Histochemistry, 87: 53-58.

49. Clark SA, Stumpf WE, Sar M, DeLuca HF \& Tanaka $Y$ (1980). Target cells for 1,25 dihydroxyvitamin $\mathrm{D}_{3}$ in the pancreas. Cell and Tissue Research, 209: 515-520.

50. Clark SA, Stumpf WE \& Sar M (1981). Effects of 1,25 dihydroxyvitamin $D_{3}$ on insulin secretion. Diabetes, 30: 382-386.

51. Stumpf WE, Sar M \& DeLuca HF (1981). Sites of action of $1,25(\mathrm{OH})_{2}$ vitamin $D_{3}$ identified by thaw-mount autoradiography. In: Cohn DV, Talmage RV \& Matthew Jr JL (Editors), Hormonal Control of Calcium Metabolism. Excerpta Medica, Amsterdam, 222-229.

52. Sar M, Stumpf WE \& DeLuca HF (1980). Thyrotropes in the pituitary are target cells for $1,25(\mathrm{OH})_{2}$ vitamin $\mathrm{D}_{3}$. Cell and Tissue Research, 209: 161-166.

53. Sar M, Miller WL \& Stumpf WE (1981). Effects of $1,25(\mathrm{OH})_{2}$ vitamin $D_{3}$ on thyrotropin secretion in vitamin $\mathrm{D}$ deficient male rats. Physiologist, 24: 70 (Abstract).

54. Muenz H, Stumpf WE \& Jennes L (1981). LHRH-Systems in the brain of platyfish. Brain Research, 221: 1-13.

55 Narbaitz R, Stumpf WE, Sar M, Huang S \& DeLuca HF (1983). Autoradiographic localization of target cells for 1-alpha,25dihydroxyvitamin $D_{3}$ in bones from fetal rat. Calcified Tissue International, 35: 177182.

56. Stumpf WE \& Jennes L (1984). The A-B-C (allocortex-brainstem-core) circuitry of endocrine-autonomic integration and regulation: A proposed hypothesis on the anatomical-functional relationships between estradiol sites of action and peptidergicaminergic neuronal systems. Peptides, 5 (Suppl 1): 221-226.

57. Clark SA, Stumpf WE, Bishop CW, DeLuca HF, Park DH \& Joh TH (1986). The adrenal: A new target organ of the calciotropic hormone 1,25-dihydroxyvitamin $\mathrm{D}_{3}$. Cell and Tissue Research, 243: 299-302.

58. Kim YS, Clark SA, Stumpf WE \& DeLuca HF (1985). Nuclear uptake of 1,25-dihydroxyvitamin $D_{3}$ in developing rodent teeth: An autoradiographic study. Anatomical Records, 212: 301-306.
59. Clark SA, Dame MC, Kim YS, Stumpf WE \& DeLuca HF (1985). 1,25-Dihydroxyvitamin $D_{3}$ in teeth of rats and humans: Receptors and nuclear localization. Anatomical Records, 212: 250-254.

60. Stumpf WE, Sar M, Chen K, Morin J \& DeLuca HF (1987). Sertoli cells in the testis and epithelium of the ductuli efferentes are targets for ${ }^{3} \mathrm{H} 1,25(\mathrm{OH})_{2}$ vita$\min \mathrm{D}_{3}$ : An autoradiographic study. Cell and Tissue Research, 247: 453-455.

61. Schleicher G, Privette TH \& Stumpf WE (1989). Distribution of soltriol $\left[1,25(\mathrm{OH})_{2}\right.$ vitamin $\mathrm{D}_{3}$ ] binding sites in male sex organs of the mouse: An autoradiographic study. Journal of Histochemistry and Cytochemistry, 37: 1083-1086.

62. Stumpf WE \& O'Brien LP (1987). $1,25(\mathrm{OH})_{2}$ Vitamin $D_{3}$ sites of action in the brain: an autoradiographic study. Histochemistry, 87: 393-406.

63. Stumpf WE (1988). Vitamin D-soltriol. The heliogenic steroid hormone: Somatotrophic activator and modulator. Discoveries from histochemical studies lead to new concepts. Histochemistry, 89: 209219.

64. Stumpf WE (1988). The endocrinology of sunlight and darkness: Complementary roles of vitamin $\mathrm{D}$ and pineal hormones. Naturwissenschaften, 75: 247-251.

65. Stumpf WE, Clark SA, O'Brien LP \& Reid FA (1988). 1,25(OH) $)_{2}$ vitamin $D_{3}$ sites of action in spinal cord and sensory ganglion. Anatomical Embryology, 177: 307-310.

66. Stumpf WE, Sar M, O'Brien LP \& Morin J (1988). Pyloric gastrin-producing cells and pyloric sphincter muscle cells are nuclear targets for ${ }^{3} \mathrm{H}-1,25(\mathrm{OH})_{2}$ vitamin $\mathrm{D}_{3}$ studied by autoradiography and immunohistochemistry. Histochemistry, 89: 447-450.

67. Stumpf WE \& Denny ME (1989). Vitamin D-soltriol, light and reproduction. American Journal of Obstetrics and Gynecology, 161: 1375-1384.

68. Stumpf WE \& Bidmon H-J (1990). Vitamin $D$-Rezeptoren und ihre organspezifische Verteilung in niederen Vertebraten (Pisces, Amphibia, Reptilia).Verhandlungen der Deutschen Zoologischen Gesellschaft, 83: 591-592.

69. Bidmon H-J \& Stumpf WE (1994). Distribution of target cells for 1,25-dihydroxyvitamin $D_{3}$ in the brain of the yellow bellied turtle Trachemis scripta. Brain Research, 640: 277-285.

70. Bidmon H-J \& Stumpf WE (1994). Distribution of the nuclear receptor for vitamin $D$ in female and male zebra finches, Taeniapygia guttata. Cell and Tissue Research, 276: 333-345. 
71. Bidmon H-J \& Stumpf WE (1996). Vitamin $D$ target systems in the brain of the green lizard Anolis carolinensis. Anatomical Embryology, 193: 145-160.

72. Bidmon H-J \& Stumpf WE (1995). Localization of specific high affinity binding sites (receptors) for ecdysteroids in invertebrates. In: Stumpf WE \& Solomon HF (Editors), Autoradiography and Correlative Imaging. Academic Press, San Diego, 83110.

73. Shughrue PJ, Stumpf WE, MacLusky NJ, Zielinski JE \& Hochberg RB (1990). Developmental changes in estrogen receptors in mouse cerebral cortex between birth and postweaning: Studied by autoradiography with $11 \beta$-methoxy-16 $\alpha$-125iodoestradiol. Endocrinology, 126: 1112-1124.

74. Shughrue PJ, Stumpf WE, Elger W, Schulze P-E \& Sar M (1991). Progestin receptor cells in mouse cerebral cortex during early postnatal development: a comparison with preoptic area and central hypothalamus using autoradiography with [125!]-progestin. Developmental Brain Research, 59: 143-155.

75. Bidmon H-J, Bartke A, Mayerhofer A, Heiss C \& Stumpf WE (1991). Vitamin Dsoltriol receptors in the choroid plexus and ependyma: Their species-specific presence. Molecular and Cellular Neurosciences, 2: 145-156.

76. Bidmon H-J, Gutkowska J, Murakami R \& Stumpf WE (1991). Vitamin D receptors in heart: Effects on atrial natriuretic factor. Experientia, 47: 958-962.
77. Stumpf WE, Bidmon H-J \& Murakami R (1991). Retinoic acid binding sites in adult brain, pituitary and retina. Naturwissenschaften, 78: 561-562.

78. Schleicher G, Bartke A, Bidmon H-J \& Stumpf WE (1993). 1,25(OH) 2 Vitamin $D_{3}$ binding sites in male sex organs of the Siberian hamster (Phodopus sungorus). An autoradiographic study. Journal of Steroid Biochemistry and Molecular Biology, 46: 331-335.

79. Schleicher G, Sar M, Bidmon H-J \& Stumpf WE (1993). Progestagen nuclear binding sites in the male genital tract of the mouse, studied by autoradiography. Journal of Steroid Biochemistry and Molecular Biology, 46: 389-393.

80. Stumpf WE, Koike N, Hayakawa N, Tokuda K, Nishimiya K, Tsuchiya Y, Hirate J, Okazaki A \& Kumaki K (1994). 1,25Dihydroxyvitamin $D_{3}$ and 22-oxa-1,25-dihydroxyvitamin $\mathrm{D}_{3}$ in vivo nuclear receptor binding in developing bone during endochondral and intramembranous ossification. Histochemistry, 102: 183-194.

81. Stumpf WE, Koike N, Hayakawa N, Hirate J, Okazaki A \& Kumaki K (1995). Nuclear receptors 1,25-dihydroxy-22-oxavitamin $\mathrm{D}_{3}(\mathrm{OCT})$ and 1,25-dihydroxyvitamin $\mathrm{D}_{3}$ in gastric neck mucous cells and gastrin endocrine cells. Histochemistry, 103: 245250.

82. Puchacz E, Stumpf WE, Stachowiak EK \& Stachowiak MK (1996). Vitamin D increases expression of the tyrosin hydroxylase gene in adrenal medullary cells. Molecular Brain Research, 36: 193-196.
83. Stumpf WE (1995). Vitamin D sites and mechanisms of action: a histochemical perspective. Reflections on the utility of autoradiography and cytopharmacology for drug targeting. Histochemistry and Cell Biology, 104: 417-427.

84. Stumpf WE (1996). Corpora non agunt nisi in loco. Drug Metabolism and Disposition, 24: 507-508.

85. Zigmond RE, Nottebohm $F$ \& Pfaff DW (1973). Androgen-concentrating cells in the midbrain of a songbird. Science, 179: 1005-1007.

86. Breedlove SM \& Arnold AP (1980). Hormone accumulation in a sexually dimorphic motor nucleus of the rat spinal cord. Science, 210: 564-566.

87. Ermisch A \& Ruehle H-J (1978). Autoradiographic demonstration of aldosteroneconcentrating neuron populations in rat brain. Brain Research, 147: 154-158.

88. Stumpf WE \& Sar M (1981). Anatomical relationships between estrogen target sites and peptidergic-aminergic neurons: Multiple activation of heterogeneous systems (MAHS). Experimental Brain Research, (Suppl 3): 29-36.

89. Kuhn TS (1970). The Structure of Scientific Revolution. 2nd edn. University of Chicago Press, Chicago.

90. Stumpf WE (1980). "Peer" review. Science, 207: 822 